\title{
Soil Water Availability on Growth and Development of Safflower Plants
}

\author{
Edna Maria Bonfim-Silva*, Ellen Cristina Alves de Anicésio, Jakeline Rosa de Oliveira, \\ Helon Hébano de Freitas Sousa, Tonny José Araújo da Silva \\ Department of Agricultural and Environmental Engineering, Institute of Agricultural Sciences and Technology, \\ Federal University of Mato Grosso, Rondonópolis, Brazil \\ Email:
}

Received 15 July 2015; accepted 21 August 2015; published 27 August 2015

Copyright (C) 2015 by authors and Scientific Research Publishing Inc.

This work is licensed under the Creative Commons Attribution International License (CC BY). http://creativecommons.org/licenses/by/4.0/

(c) (i) Open Access

\section{Abstract}

Safflower (Carthamus tinctorius L.) is a promising culture to be widespread in Brazil. However, the lack of basic knowledge about cultivation techniques, such as water demand by the culture, is still obstacle to the expansion of safflower in that country. The objective was, then, to evaluate the effect of the soil water availability on growth and development of safflower in the Cerrado soil of Mato Grosso, Brazil. The experiment was conducted in a greenhouse, in a completely randomized design with five water availabilities $(25 \%, 50 \%, 75 \%, 100 \%$ and $125 \%$ of the maximum water holding capacity in the soil) and four replications. Maintenance soil moisture was performed by gravimetric method with daily weighing of experimental units. The variables analyzed were: plant height, stem diameter, number of leaves, number of heads, heads diameter, dry mass of shoots, heads, and roots. The results were submitted to analysis of variance and regression test at $5 \%$ probability by SISVAR program. All variables set to the quadratic regression model, showing the best results in the water availability between $64 \%$ and $76 \%$. Safflower is shown to be more sensitive to water stress with increased tolerance to water deficit in the soil than to flooding.

\section{Keywords}

Carthamus tinctorius L., Field Capacity, Water Stress, IMA 0213

\section{Introduction}

The need to be unlinked from the dependence on exhaustible sources has led increasingly to the search for sustainable energy production systems. Thus, the importance of oil crops, among them the safflower (Carthamus

*Corresponding author.

How to cite this paper: Bonfim-Silva, E.M., de Anicésio, E.C.A., de Oliveira, J.R., de Freitas Sousa, H.H. and da Silva, T.J.A. (2015) Soil Water Availability on Growth and Development of Safflower Plants. American Journal of Plant Sciences, 6, 20662073. http://dx.doi.org/10.4236/ajps.2015.613207 
tinctorius L.), has increased, especially with the interest in biofuel production [1].

The use of safflower in human activity is well known, whether in the production of dyes [2] [3] in medicine [4], or in human consumption and industrial use, since the seeds of this plant species have high oil contents (35\% to $40 \%$ ) of good quality [5].

The safflower culture has important agronomic traits, such as tolerance to water deficit [6], to high temperatures, to strong and hot winds, to low relative humidity of the air and to saline soils [7]. Hence, it is presented as an option to be introduced in the Brazilian Cerrado in the period between harvests, diversifying production and increasing the income of the producer.

Nonetheless, although there is adaptation of the safflower to the climate of semi-arid regions, its water requirement is not yet defined [7], mainly to the Brazilian soil conditions, where studies are being initiated.

There are papers that relate the development of safflower with soil water availability [8]-[10], however, they do not exploit the full range that is between the saturation and the condition of water scarcity, and therefore do not indicate the optimum point of the soil moisture for the full development of this culture.

Both deficiency and excess of water in plants can cause significant changes in its metabolism, reducing growth, development [11] and thus influencing the potential for crop production.

Considering soil water from the energetic point of view, its movement takes place from the point where its total energy is higher (wet) to the point where it is lower (dry) [12]. The drier the soil, the lower the hydraulic conductivity of it.

To compensate for the resistance to water flow in the soil, the potential in the root decreases to its limit, then physiological mechanisms cause the closure of the stomata in the leaves, increasing the total resistance of the soil-plant-atmosphere path, thereby reducing the flow of water. When there is stomatal closure, there is also, collaterally, reduced CO2 absorption, which is limiting to plant growth under optimal lighting conditions [13].

In situations of very wet soils, with less negative matric potentials, the anaerobic zones are found. They cause plant stress due to lack of oxygen to the root system.

In this context, the objective was to evaluate the effect of water availability in the growth and development of safflower in soil of the Cerrado of Mato Grosso, Brazil.

\section{Materials and Methods}

The study was conducted in a greenhouse located at the geographic coordinates of $16^{\circ} 27^{\prime} 52^{\prime \prime} \mathrm{S}$ and $54^{\circ} 34^{\prime} 46^{\prime \prime} \mathrm{W}$, at the Federal University of Mato Grosso, Campus Rondonópolis-MT, Brazil.

The soil used in the experiment, from an area under Cerrado vegetation, was collected in the $0-0.20 \mathrm{~m}$ layer of an Oxisol. Chemical and granulometric analyzes were performed for its characterization (Table 1), according to reference [14].

Liming with dolomite lime (PRNT $=80.3 \%$ ) was performed to raise the base saturation to $60 \%$. Soil moisture was maintained at $60 \%$ of its maximum water holding capacity, remaining incubated for 30 days.

After the incubation period of the soil with limestone, basic fertilization was performed with 50, 150 and 100 $\mathrm{mg} \cdot \mathrm{dm}^{-3}$ of nitrogen $(\mathrm{N})$, phosphorus $\left(\mathrm{P}_{2} \mathrm{O}_{5}\right)$ and potassium $\left(\mathrm{K}_{2} \mathrm{O}\right)$, respectively, having as source urea, simple superphosphate and potassium chloride.

Each plot consisted of a plastic pot with a capacity of $3.5 \mathrm{dm}^{3}$ containing four plants. The experimental design was completely randomized with five water availabilities $(25 \%, 50 \%, 75 \%, 100 \%$ and $125 \%$ of the maximum capacity of soil water retention) and four replications. The maximum capacity of soil water retention in the pots was maintained by the gravimetric method with daily weighing of experimental units, according to reference [15].

Ten safflower seeds per pot were sown, and the thinning was carried out at ten days after sowing, leaving four plants per pot.

Table 1. Chemical and granulometric characterization in the $0-0.20 \mathrm{~m}$ layer of the Oxisol.

\begin{tabular}{|c|c|c|c|c|c|c|c|c|c|c|c|c|c|}
\hline $\mathrm{pH}$ & $\mathrm{P}$ & $\mathrm{K}$ & $\mathrm{Ca}$ & $\mathrm{Mg}$ & $\mathrm{H}$ & $\mathrm{Al}$ & SB & CEC & $\mathrm{V}$ & O.M. & Sand & Silt & Clay \\
\hline $\mathrm{CaCl}_{2}$ & \multicolumn{2}{|c|}{$\mathrm{mg} \cdot \mathrm{dm}^{-3}$} & & \multicolumn{4}{|c|}{------ $\mathrm{cmol}_{\mathrm{c}} \cdot \mathrm{dm}^{-3}$} & & $\%$ & $\mathrm{~g} \mathrm{dm}^{-3}$ & & -1 & \\
\hline 4.1 & 2.4 & 28 & 0.3 & 0.2 & 4.2 & 1.1 & 0.6 & 5.9 & 9.8 & 22.7 & 549 & 84 & 367 \\
\hline
\end{tabular}

Phosphorus (P), Potassium (K), Calcium (Ca), Magnesium (Mg), Hydrogen (H), Aluminum (Al), Sum of Bases (SB), Cation Exchange Capacity (CEC), Calcium Chloride $\left(\mathrm{CaCl}_{2}\right)$, base saturation $(\mathrm{V})$ and Organic Matter (O.M.). 
In the first ten days after planting, soil moisture was maintained at $60 \%$ of the maximum capacity of the soil water retention to ensure good plant growth in the establishment phase. After this period, each plot was irrigated so as to keep the water availability corresponding to treatments.

At 60 days, the following variables were evaluated: plant height, stem diameter, number of leaves, number of heads, heads diameter, dry mass of shoots, heads, and roots.

Height was measured with a ruler graduated from the ground level to the highest part of each plant. The diameter of stem and heads was obtained by measurement using caliper rule.

The cut of the shoot was done close to the ground, and leaves + stem were separated from heads to determine their respective dry masses. The roots were collected and washed on sieve mesh of $4 \mathrm{~mm}$. All the collected material was packed in paper bag and subjected to drying in an oven with forced air at $65^{\circ} \mathrm{C}$ to constant weight and, then, it was weighed.

The results were submitted to analysis of variance by $\mathrm{F}$ test and, when significant, it was applied regression testing, both at 5\% probability, using the statistical program SISVAR [16].

\section{Results and Discussion}

There were significant differences for all analysed variables regarding soil water availabilities, which set to the quadratic regression model.

The height of safflower plants was influenced by water availability, being the greatest plant height, of $51 \mathrm{~cm}$ (Figure 1(a) and Figure 1(b)), provided by the water availability of $72.5 \%$.

The knowledge of the influence of water availability in the growth of a crop is essential in situations where the plant in question will have its production harvested mechanically, especially when there is the possibility of investment savings when it can be used the same implements used in other crops, such as soybeans and cotton.

These results corroborate those of reference [5] when studying the behavior and adaptability of safflower cultivars to oil, being found reduced plant height from $113 \mathrm{~cm}$ to $73 \mathrm{~cm}$, from one year to the other due to low rainfall in the growing season.

The low availability of aeration does not favor the growth of safflower plants. This statement is validated by the results shown by the treatment in which the water supply was above $100 \%$ of the maximum water holding capacity in the soil. As in this study, the references [8] [9] observed that the safflower is a crop sensitive to excess of water.

For stem diameter, the water availability that provided the largest diameter $(4 \mathrm{~cm})$ was of $77 \%$ (Figure 2). In this context, the reference [17] reported that water stress may directly influence the stem diameter reducing cell expansion and cell wall formation and indirectly reducing the availability of carbohydrates or influencing the production of growth regulators.

The stem diameter reflects the robustness of the plant, based on this variable, when compared between plants of the same species; one can infer the propensity to lodging. Relevant characteristic in plants whose cultivation is mechanized, since the non-tipping facilitates its handling, treatment, and harvest [18]. The lodging in safflower culture can bring harm, among other steps, to mechanized harvesting.

The number of leaves was influenced by the soil water availability with greater value in the availability of $72 \%$ (Figure 3). Plants submitted to water stress regimes react in order to save water for later periods [19], among these

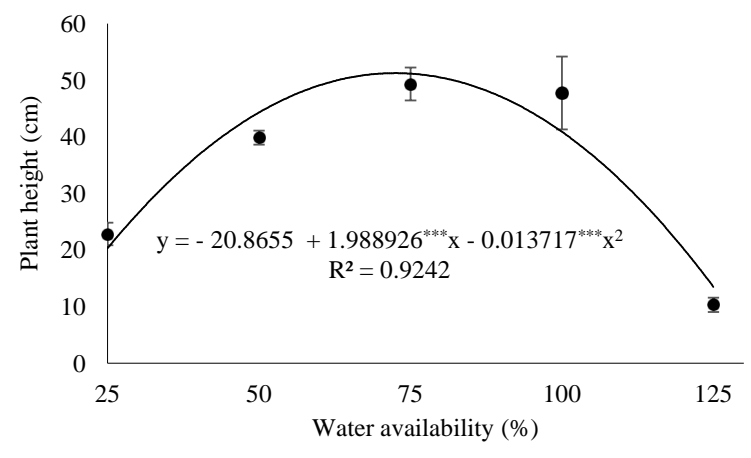

(a)

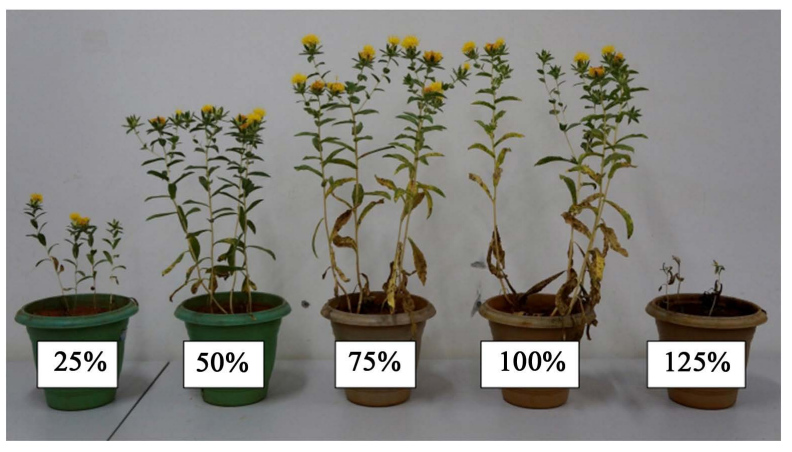

(b)

Figure 1. Plant height ((a) and (b)) of safflower subject to soil water availabilities. ${ }^{* * *}$ Significant at $0.1 \%$ probability. 


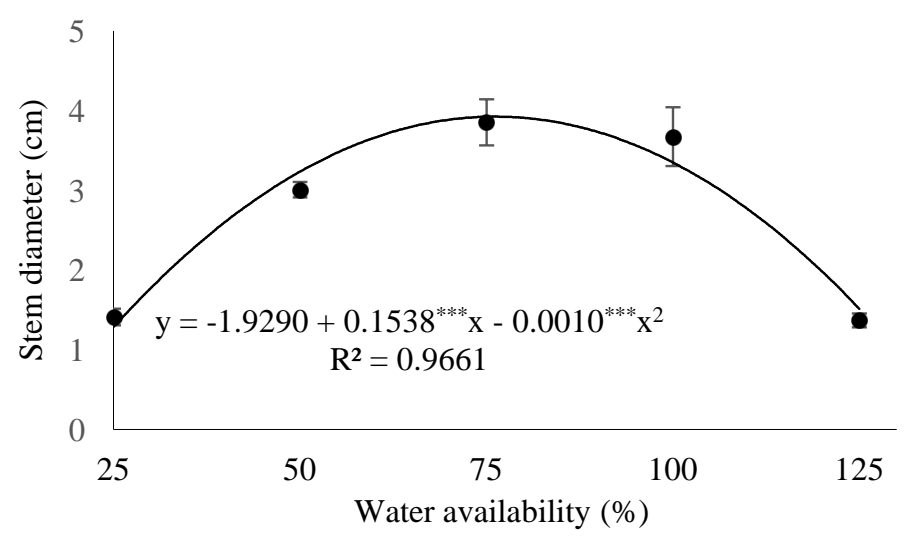

Figure 2. Stem diameter of safflower plants subject to soil water availability. Significant at $0.1 \%$ probability.

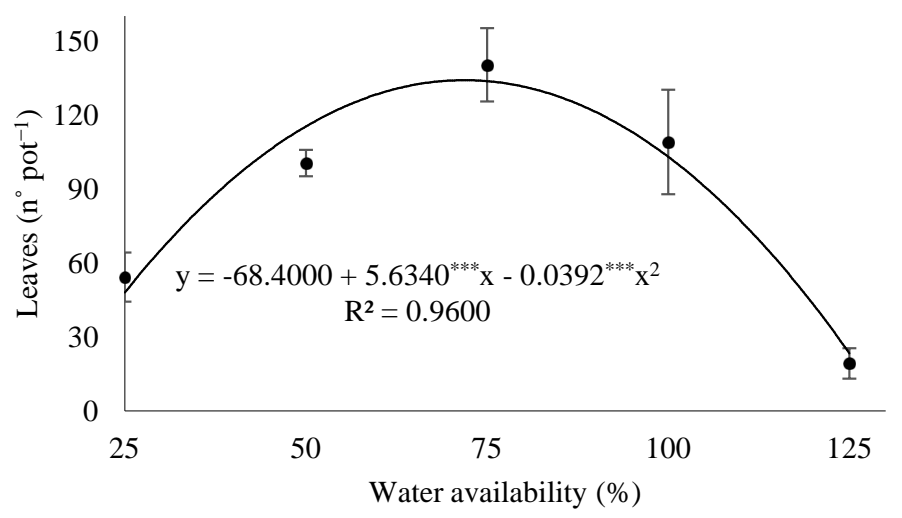

Figure 3. Number of leaves of safflower plants subject to soil water availability. ${ }^{* * *}$ Significant at $0.1 \%$ probability.

reactions may be the reduction in the number of leaves that occurs due to reductions or inhibitions in the leaf initiation rate, or even as a result of accelerated foliar senescence induction.

The leaf senescence is one of the mechanisms to prevent dehydration that, notwithstanding, takes a sharp decline in productivity potential, even after the elimination of the deficit [20].

The study of the number of leaves highlights the importance of measuring this characteristic, as indicative of the crop yield, for being these organs the main site for the occurrence of the photosynthetic process [21].

The largest numbers and diameter of heads were obtained in the water availabilities of $71 \%$ and $61 \%$, respectively (Figure 4(a) and Figure 4(b)).

The number of heads per plant is directly related to the final production of the culture. Nonetheless, the head diameter is also relevant in research because heads with larger diameters, in theory, have a greater ability to flower formation and therefore higher number of seeds, which may contribute, along with other components, to increased productivity [21]-[23].

The greatest production of dry mass of shoots of safflower was observed in plants submitted to the water availability of 76\% (Figure 5). In this context, it can be seen that safflower grown in soil moisture at field capacity ( $100 \%$ of the maximum capacity of the soil water retention) can be detrimental to the growth and development of the crop.

The results of this study are consistent with those observed by reference [24], who found that treatment in which the soil remained at $80 \%$ of its water holding capacity favored the dry mass yield of leaves and stalk of sunflower plants (Helianthus annuus).

The reference [25], studying the safflower culture, observed, at 75 days after sowing, a reduction in the yield of safflower culture of $65 \%$ when compared the treatment with and without irrigation.

The lower water availability may lead to reduced cell expansion, stomatal closure, reduction in photosynthesis, 


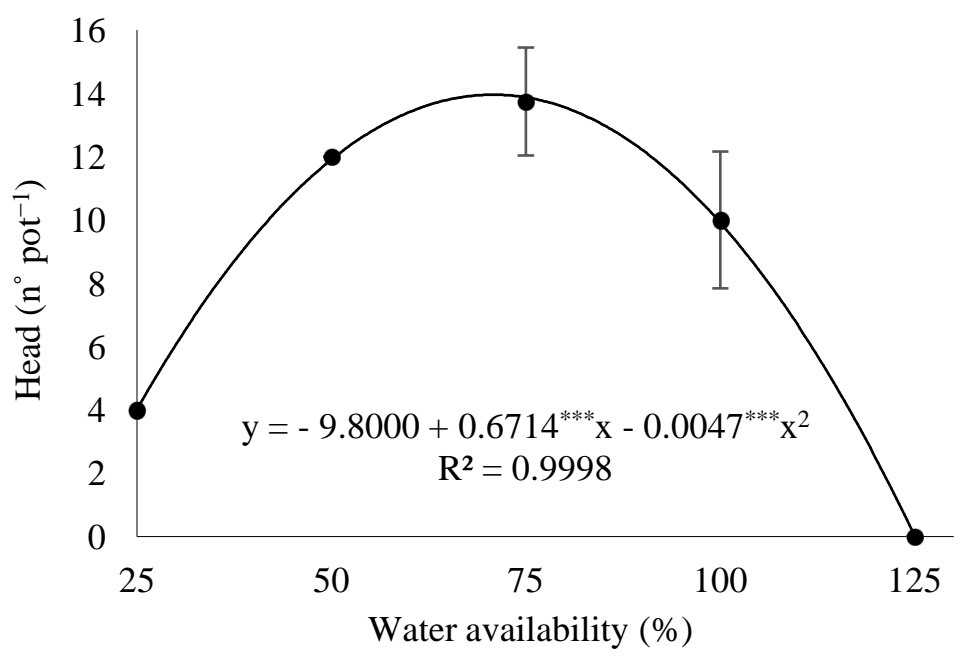

(a)

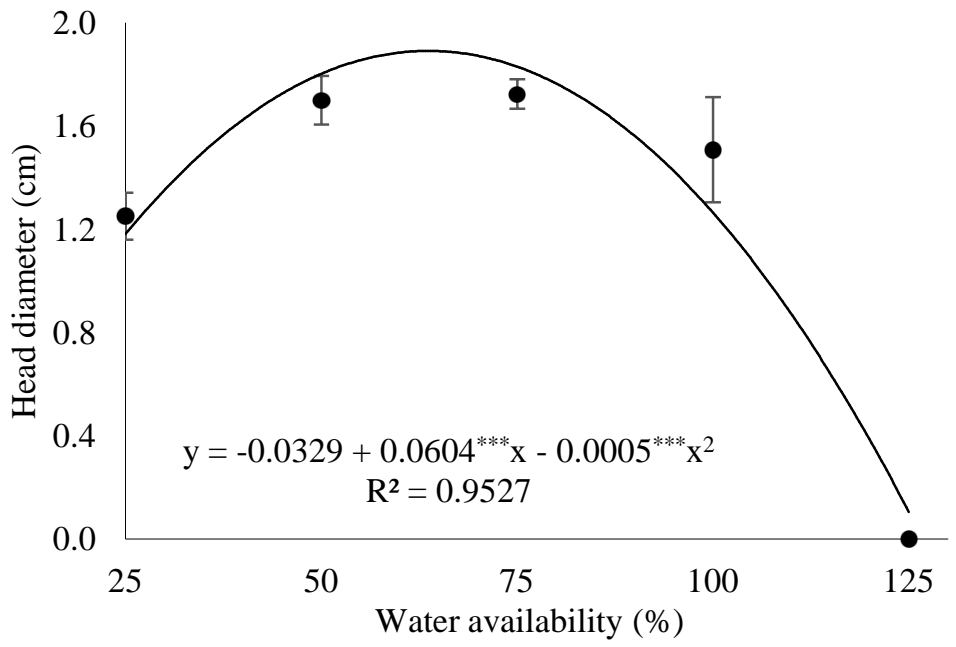

(b)

Figure 4. Number of heads (A) and Head diameter (B) of safflower plants subject to soil water availability. ${ }^{* * *}$ Significant at $0.1 \%$ probability.

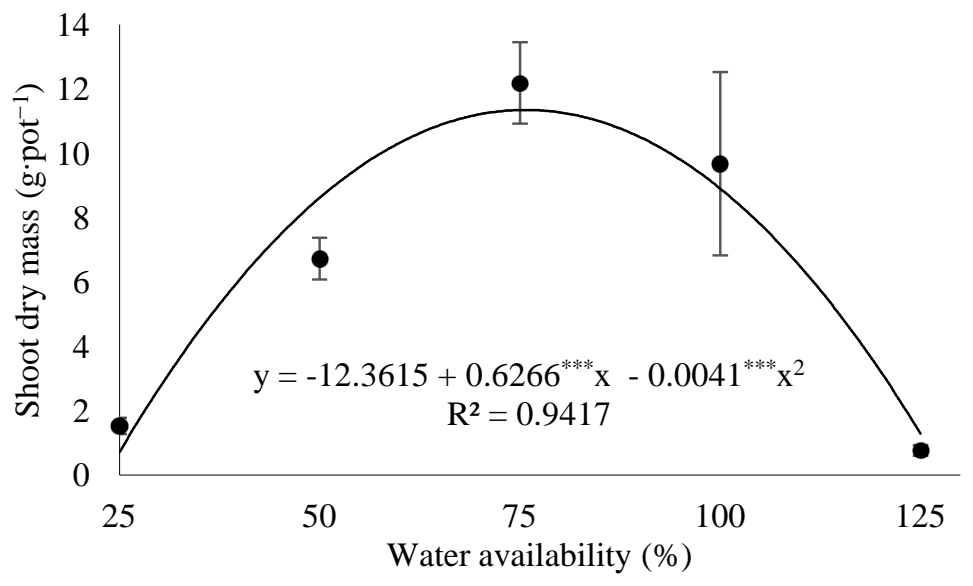

Figure 5. Shoots dry mass of safflower plants subject to soil water availability. Significant at $0.1 \%$ probability. 
severely affecting the yield of biomass of shoot and root. However, in flooded soil conditions, there is a lack of oxygen to the roots, which causes the death of the root tissues by favoring lactic fermentation and acidosis in the cells, also with the probability of leading to reduced absorption of nutrients and water by lack of energy, hindering the growth of shoots [17].

The dry mass of heads showed higher production with the soil at $72 \%$ of its maximum water holding capacity, an increase of $83 \%$ compared to treatment with water deficit (water availability of 25\%) (Figure 6).

Thus, it can be observed that in conditions of water excess in the soil (125\% water availability), the safflower plant did not produce heads, reproductive structure that houses the grains to oil extraction. Hence, safflower shows to be more sensitive to flooding than to drought, although in this last condition there is also production reduction (Figure 7).

The highest production of dry mass of roots of the safflower was observed in plants submitted to the water availability of 74\% (Figure 8). This result goes against with the findings for the reference [24] studying sunflower plants in levels of soil water retention capacity. These authors found that soil moisture up to the level of $115 \%$ of its maximum water holding capacity provided increment in the dry mass production of sunflower roots.

Through this study, it is possible to realize a marked reduction of the roots in the treatment with flooded soil (125\% of the maximum water retention), demonstrating the susceptibility of the safflower to the excess of water in the soil. The reference [26] also found a reduction in the growth of sunflower roots grown in soil under hypoxia condition.

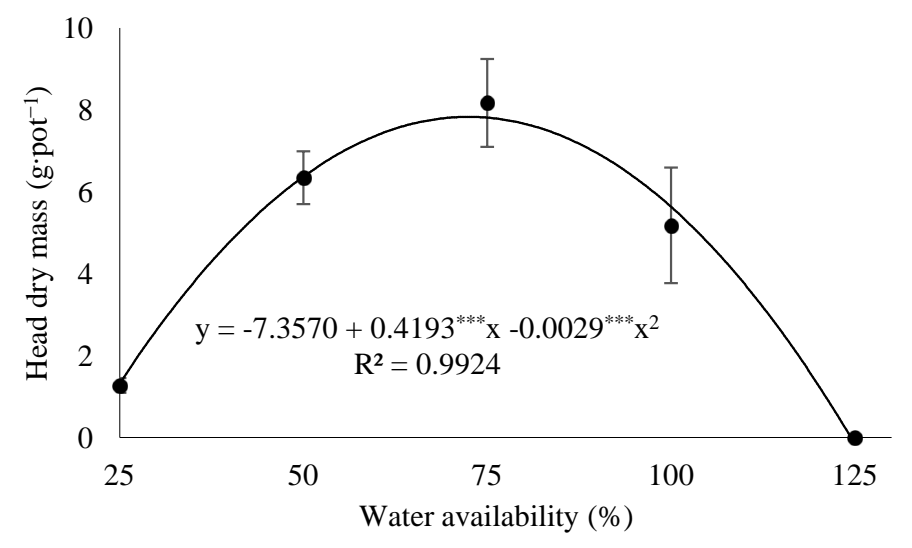

Figure 6. Head dry mass of heads of safflower plants subject to soil water availability. ${ }^{* * *}$ Significant at $0.1 \%$ probability.

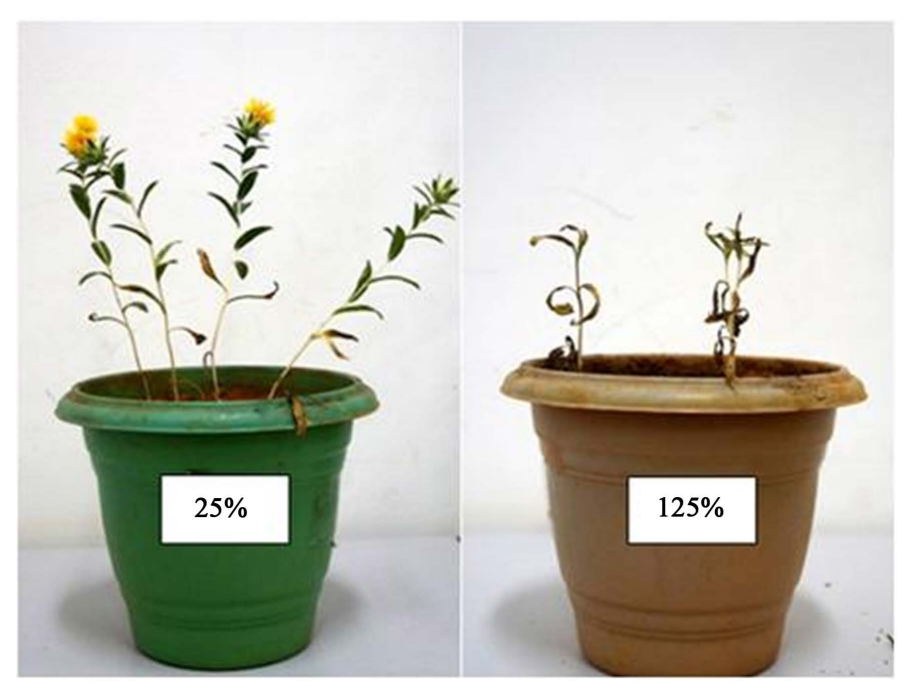

Figure 7. Safflower plants subject to water availabilities of $25 \%$ (water deficit) and $125 \%$ (flooded soil). 


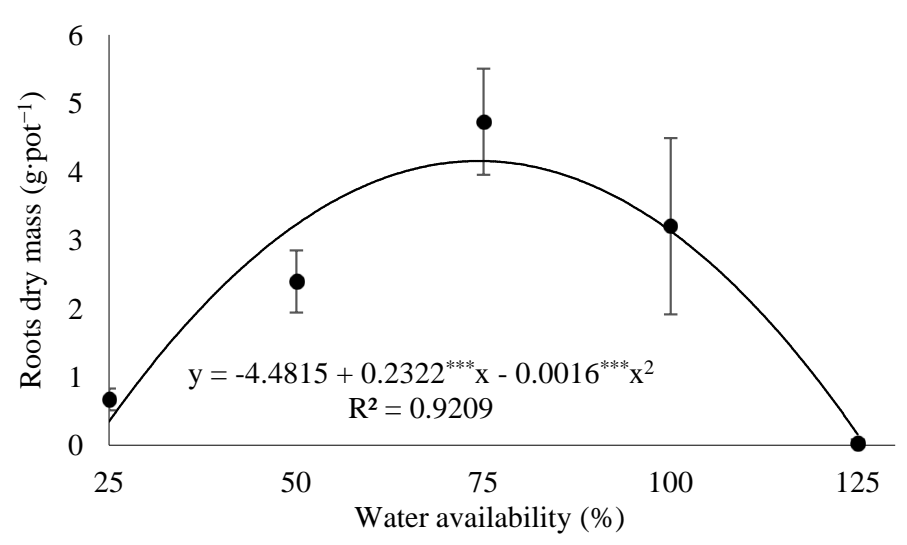

Figure 8. Dry mass of roots of safflower plants subject to soil water availability. ${ }^{* * *}$ Significant at $0.1 \%$ probability.

The excess of water in the soil causes immediate reduction in gas exchange between the plant and the environment. The anoxia or hypoxia suffered by the root system in flooded plants causes immediate drop in respiration of roots and can cause death [27].

The expression of data followed the same adjustment model for all variables, the quadratic regression. The graph curve of this type of function is a half upward and half downward parabola, divided by an inflection point. Although it is an expected behavior for works of this nature, as extreme treatments are stressful for most crops [13], the definition of the optimum point will serve as a basis for decision making in future work, both for experiments in controlled conditions and for the basics of management in field conditions.

The response of growth and development of safflower depending on the water availabilities in the soil demonstrates the need for more detailed studies on the water availability for this culture. The reference [10] observed that the reduction in yield and dry mass production was more prominent when there was a lack of water during flowering than when the shortage of water was given before or after flowering.

\section{Conclusion}

The soil water availability influences the growth and development of safflower plants with better results in the ranges between $61 \%$ and $76 \%$ of maximum water holding capacity in the soil. Water stresses both by the deficit and the excess of water in the soil reduce the dry mass production of safflower. Safflower is more sensitive to water stress with increased tolerance to water deficit in the soil than to flooding.

\section{References}

[1] Dordas, C.A. and Sioulas, C. (2009) Dry Matter and Nitrogen Accumulation, Partitioning, and Retranslocation in Safflower (Carthamus tinctorius L.) as Affected by Nitrogen Fertilization. Field Crops Research, 110, 35-43. http://dx.doi.org/10.1016/j.fcr.2008.06.011

[2] Kim, H.-W., Hwang, K.-E., Song, D.-H., Kim, Y.-J., Ham, Y.-K., Lim, Y.-B., Jeong, T. J., Choi, Y.-S. and Kim, C.-J. (2015) Wheat Fiber Colored with a Safflower (Carthamus tinctorius L.) Red Pigment as a Natural Colorant and Antioxidant in Cooked Sausages. LWT-Food Science and Technology, 64, 350-355. http://dx.doi.org/10.1016/j.lwt.2015.05.064

[3] Torabi, B., Adibniya, M. and Rahimi, A. (2015) Seedling Emergence Response to Temperature in Safflower: Measurements and modeling. International Journal of Plant Production, 9, 393-412. http://ijpp.gau.ac.ir/article_2223_336.html

[4] Wang, Y., Tang, C.Y. and Zhang, H. (2015) Hepatoprotective Effects of Kaempferol 3-O-rutinoside and Kaempferol 3-O-glucoside from Carthamus tinctorius L. on $\mathrm{CCl}_{4}$-Induced Oxidative Liver Injury in Mice. Journal of Food and Drug Analysis, 23, 310-317. http://dx.doi.org/10.1016/j.jfda.2014.10.002

[5] Giayetto, O., Fernandez, E.M., Asnal, W.E., Cerioni, G.A. and Cholaky, L. (1999) Comportamiento de cultivares de cártamo (Carthamus tinctorius L.) en la region de Rio Cuarto. Investigación Agraria: Producción y protección vegetales, 14, 203-215.

http://www.scielo.br/scielo.php?script=sci_nlinks\&ref=000073\&pid=S0103-8478201200120000700005\&lng=pt 
[6] Lovelli, S., Perniola, M., Ferrara, A. and Di Tommaso, T. (2007) Yield Response Factor to Water (Ky) and Water Use Efficiency of Carthamus tinctorius L. and Solanum melongena L. Agricultural Water Management, 92, 73-80. http://dx.doi.org/10.1016/j.agwat.2007.05.005

[7] Kizil, S., Çakmak, Ö., Kirici, S. and İnan, M. (2008) A Comprehensive Study on Safflower (Carthamus tinctorius L.) in Semi-Arid Conditions. Biotechnology \& Biotechnological Equipment, 22, 947-953. http://dx.doi.org/10.1080/13102818.2008.10817585 http://www.tandfonline.com/action/showCitFormats?doi=10.1080/13102818.2008.10817585

[8] Quiroga, A.R., Díaz-Zorita, M. and Buschiazzo, D.E. (2001) Safflower Productivity as Related to Soil Water Storage and Management Practices in Semiarid Regions. Communications in Soil Science and Plant Analysis, 32, 2851-2862. http://www.tandfonline.com/doi/pdf/10.1081/CSS-120000967\#.VcQJsiZViko

[9] Bassil, E.S. and Kaffka, S.R. (2002) Response of Safflower (Carthamus tinctorius L.) Tosaline Soils and Irrigation: II. Crop Response to Salinity. Agricultural Water Management, 54, 81-92. http://dx.doi.org/10.1016/S0378-3774(01)00144-5

[10] Movahhedy-Dehnavy, M., Modarres-Sanavy, S.A.M. and Mokhtassi-Bidgoli, A. (2009) Foliar Application of Zinc and Manganese Improves Seed Yield and Quality of Safflower (Carthamus tinctorius L.) Grown under Water Deficit Stress. Industrial Crops and Products, 30, 82-92. http://dx.doi.org/10.1016/j.indcrop.2009.02.004

[11] Leite, R.M.V.B., Brighenti, A.M. and Castro, C. (2005) Girassol no Brasil. Embrapa Soja, Londrina.

[12] Libardi, P.L. (2012) Dinâmica da água no solo. EDUSP, São Paulo.

[13] Jong van Lier, Q. (2010) Física do Solo. Sociedade Brasileira de Ciência do Solo, Viçosa.

[14] Embrapa (1997) Manual de métodos de análise de solo. Rio de Janeiro.

[15] Bonfim-Silva, E.M., Silva, T.J.A., Cabral, E.A., Kroth, B.E. and Rezende, D. (2011) Desenvolvimento Inicial de Gramíneas Submetidas ao Estresse Hídrico. Revista Caatinga, 24, 180-186. http://periodicos.ufersa.edu.br/revistas/index.php/sistema/article/view/1871/4729

[16] Ferreira, D.F. (2011) Sisvar: Um sistema computacional de estatística. Ciência e Agrotecnologia, 35, 1039-1042. http://www.scielo.br/scielo.php?pid=S1413-70542011000600001\&script=sci_arttext

[17] Taiz, L. and Zeiger, E. (2013) Fisiologia vegetal. Artmed, Porto Alegre.

[18] Biscaro, G.A., Machado, J.R., Tosta, M.S., Mendonça, V., Soratto, R.P. and Carvalho, L.A. (2008) Adubação nitrogenada em cobertura no girassol irrigado nas condições de Cassilândia-MS. Ciência e Agrotecnologia, 32, 1366-1373. http://dx.doi.org/10.1590/S1413-70542008000500002 http://www.scielo.br/pdf/cagro/v32n5/02.pdf

[19] Santos, R.S. and Carlesso, R. (1998) Déficit hídrico e os processos morfológico e fisiológico das plantas. Revista Brasileira de Engenharia Agrícola e Ambiental, 2, 287-294. http://www.agriambi.com.br/revista/v2n3/287.pdf

[20] Gonçalves, M.R. and Passos, C.A.M. (2000) Crescimento de cinco espécies de eucalipto submetidas a déficit hídrico em dois níveis de fósforo. Ciência Florestal, 10, 145-161. http://coral.ufsm.br/cienciaflorestal/artigos/v10n2/art12v10n2.pdf

[21] Benincasa, M.M.P. (2003) Análise de crescimento de plantas. FUNEP, Jaboticabal.

[22] da Silva, C.J. (2013) Caracterização agronômica e divergência genética de acessos de cártamo. 51f. Tese. Universidade Estadual Paulista, Faculdade de Ciências Agronômicas, Botucatu. http://www.pg.fca.unesp.br/Teses/PDFs/Arq0958.pdf

[23] Al-Doori, S.A.M. (2013) Performance of Some Safflower Genotypes (Carthamus tinctorius L.) According to Varying Row Spacing and Nitrogen Fertilizer Levels. Journal of Tikrit University for Agriculture Sciences, 13, 15-20. http://jtuas.com/artical-PDF-13-3-2013/15-20.pdf

[24] Dutra, C.C., Prado, E.A.F., Paim, L.R. and Scalon, S.P.Q. (2012) Desenvolvimento de plantas de girassol sob diferentes condições de fornecimento de água. Semina, 33, 2657-2668. http://www.uel.br/revistas/uel/index.php/semagrarias/article/download/8200/11763

[25] Istanbulluoglu, A., Gocmen, E., Gezer, E., Pasa, C. and Konukcu, F. (2009) Effects of Water Stress at Different Development Stages on Yield and Water Productivity of Winter and Summer Safflower (Carthamus tinctorius L.). Agricultural Water Management, 96, 1429-1434. http://dx.doi.org/10.1016/j.agwat.2009.04.004

[26] Letey, J., Stolzi, H. and Blank, G.B. (1962) Effect of Duration of Timing of Low Soil Oxygen Content on Shoot and Root Growth. Agronomy Journal, 54, 34-37. http://dx.doi.org/10.2134/agronj1962.00021962005400010011x https://dl.sciencesocieties.org/publications/aj/pdfs/54/1/AJ0540010034

[27] Liao, C.T. and Lin, C.H. (2001) Physiological Adaptation of Crop Plants to Flooding Stress. Proceedings of the National Science Councill, 25, 148-157. http://www.plantstress.com/articles/waterlogging_m/crop\%20tolerance\%20review\%202001.pdf 